\title{
MODEL PEMBELAJARAN BERBASIS MASALAH BERBANTUAN SIMULASI KOMPUTER UNTUK MENINGKATKAN KETERAMPILAN BERPIKIR KRITIS CALON GURU FISIKA
}

\author{
Lovy Herayanti, Habibi \\ Program Studi Pendidikan Fisika \\ IKIP Mataram, NTB, 83125 \\ Mataram, Indonesia \\ Email: lovy_fis@yahoo.com
}

\begin{abstract}
This study aims to examine the effectiveness of the applying of problem-based learning with computer simulation toward the critical thinking skills of pre-service physics teachers. This is necessary because critical thinking skills do not develop without the explicit and deliberate effort invested in its development. The combination with computer simulations are considered essential to overcome the difficulties learn abstract concepts in physics. This is research an experimental research. The subjects of this study were students at the Department of Physics Education, FPMIPA IKIP Mataram. The research instruments are test of critical thinking skills and questionnaire. The results showed a significant difference between students' critical thinking skills experimental class and control class, where an increase in the experimental class is higher than the control class. Students also gave a positive response to a given model.
\end{abstract}

Keywords: Problem based learning, Computer simulation, Critical thinking skills

\section{PENDAhuluan}

Kualitas pendidikan sains saat ini belum menunjukkan relevansi yang tinggi dengan kebutuhan masyarakat. Pendidikan sains khususnya di sekolah seakan-akan tidak berdampak dalam cara hidup dan cara berpikir di masyarakat. Selain relevansi dengan kebutuhan, permasalahan penting dalam pembelajaran sains adalah rendahnya kualitas pembelajaran pada berbagai jenjang pendidikan. Hal ini disebabkan antara lain masih kurangnya penguasaan materi oleh guru-guru sains. Berdasarkan hasil uji kompetensi guru SMA oleh pusat kurikulum dan pusat sistem pengujian Balitbang Depdiknas, diperoleh rata-rata penguasaan kurikulum sebesar 4,33 dan rata-rata nilai penguasaan mata pelajaran fisika 4,86 sedangkan untuk guru SMP rata-rata nilai penguasaan kurikulum 4,17 dan rata-rata penguasaan mata pelajaran fisika 6,64 pada skala 10 .

Penelitian tentang model pembelajaran berbasis masalah yang pernah dilakukan menunjukkan adanya pengaruh positif model PBM. Model PBM dengan pendekatan inkuiri dapat memberikan peningkatan yang signifikan pada penguasaan konsep listrik mahasiswa calon guru. Beberapa indikator keterampilan generik sains seperti kemampuan inferensi logika dan kemampuan membangun konsep juga mengalami peningkatan yang lebih tinggi dibandingkan mahasiswa yang belajar secara konvensional, ${ }^{[1]}$ (Herayanti et. al, 2009; ${ }^{[2]}$ Herayanti, 2012).

${ }^{[3]}$ Tan, Oon-Seng, et. al (2009) menyatakan bahwa belajar yang sukses sering dimulai dengan keasyikan dengan masalah, diikuti dengan mengambil kepemilikan masalah dan memanfaatkan berbagai dimensi pemikiran. Model pembelajaran berbasis masalah dapat membantu mahasiswa meningkatkan rasa ingin tahu, keterampilan berpikir, dan kreativitas mahasiswa.

Begitupun halnya dengan pemanfaatan teknologi komputer dalam pembelajaran yang juga memberikan pengaruh positif dalam perolehan hasil belajar maupun keterampilan berpikir mahasiswa. ${ }^{[4]}$ Gunawan (2011) menemukan adanya peningkatan yang signifikan pada penguasaan konsep fisika mahasiswa yang belajar menggunakan simulasi interaktif. Penguasaan konsep abstrak menjadi lebih baik karena membantu mahasiswa dalam menerima hal-hal yang sebelumnya sulit diterima dan dilihat secara langsung.

Sebagai matakuliah dasar, fisika dasar tidak hanya mendasari ilmu-ilmu eksakta atau melengkapi matakuliah pokok, tetapi juga memberikan keluasan wawasan keilmuan serta melatih mahasiswa berpikir kritis, objektif, dan rasional. Penguasaan konsep yang baik pada materi fisika dasar akan membantu mahasiswa untuk memahami materi fisika yang lebih tinggi, karena fisika dasar merupakan landasan bagi tingkat-tingkat fisika berikutnya. Selain itu penguasaan konsep yang baik dalam fisika dasar akan membantu membekali calon guru ketika mengajar di sekolah kelak, karena kedalaman dan keluasan materi fisika dasar merupakan kelanjutan dan pemantapan fisika di sekolah menengah. Pentingnya peranan fisika dasar khususnya dalam pembekalan calon guru 
mengharuskan pengajarnya membuat perencanaan pembelajaran dengan baik sehingga mahasiswa dapat memahami konsep-konsep dasar fisika secara optimal (Gunawan, 2008).

Model pembelajaran fisika dasar yang selama ini diterapkan di Mataram belum secara optimal membantu mahasiswa meningkatkan kemampuan dalam memahami konsep-konsep dasar fisika. Hal ini dapat dilihat dari perolehan rata-rata skor nilai akhir fisika dasar mahasiswa salah satu LPTK di Mataram yang masih rendah, seperti rata-rata perolehan nilai fisika dasar pada tahun 2006 sebesar 62,9 dan pada tahun 2007 sebesar 54,5. Selain itu, pembelajaran fisika dasar secara konvensional belum memberikan konstribusi yang cukup dalam upaya membekali keterampilan-keterampilan berpikir bagi mahasiswa, baik keterampilan generik sains maupun keterampilan berpikir yang lebih tinggi.

Salah satu inovasi pembelajaran yang ditawarkan untuk membantu mahasiswa meningkatkan penguasaan konsepnya adalah dengan model pembelajaran berbasis masalah (Problem Based Learning) dengan pendekatan inkuiri. Pembelajaran berbasis masalah adalah suatu model pembelajaran yang menggunakan masalah sebagai titik tolak pembelajaran. Masalah tersebut adalah masalah yang memenuhi konteks dunia nyata baik yang ada di dalam buku teks maupun dari sumber lain seperti peristiwa yang terjadi di lingkungan sekitar, peristiwa dalam keluarga atau kemasyarakatan untuk belajar tentang berpikir dan keterampilan pemecahan masalah serta untuk memperoleh pengetahuan dan konsep yang esensi dari materi pelajaran. Model PBM sebagai salah satu model yang mengembangkan berbagai keterampilan berpikir perlu diterapkan dalam pembelajaran di kelas.

Beberapa penelitian model PBM yang telah dilakukan diantaranya penelitian Mulhayatiah (2005) yang menyatakan peningkatan penguasaan konsep siswa lebih baik dibanding model pembelajaran konvensional. Selain penguasaan konsep, pembelajaran berbasis masalah dengan pendekatan inkuiri juga dapat meningkatkan keterampilan generik sains mahasiswa. Herayanti (2009) menyatakan pembelajaran berbasis masalah dengan pendekatan inkuiri dapat meningkatkan keterampilan generik sains mahasiswa calon guru, khususnya pada kemampuan pengamatan tidak langsung dan inferensi logika.

\section{TinjauAn Pustaka}

\section{A. Model Pembelajaran Berbasis Masalah}

Pembelajaran berbasis masalah (problem based learning) adalah suatu model pembelajaran yang menggunakan masalah sebagai titik tolak (starting point) pembelajaran. Masalah tersebut adalah masalah yang memenuhi konteks dunia nyata baik yang ada di dalam buku teks maupun dari sumber lain seperti peristiwa yang terjadi di lingkungan sekitar, peristiwa dalam keluarga atau kemasyarakatan untuk belajar tentang berpikir kritis dan keterampilan pemecahan masalah serta untuk memperoleh pengetahuan dan konsep yang esensial dari materi pelajaran. Karakteristik masalah yang baik dalam implementasi PBM adalah: (1) melibatkan dan berorientasi pada dunia nyata; (2) menggambarkan struktur yang kompleks; (3) menghasilkan berbagai hipotesis, (4) memerlukan kerja tim, (5) konsisten dengan hasil belajar yang diinginkan; (6) membangun pengetahuan atau pengalaman sebelumnya; dan (7) meningkatkan pengembangan keterampilan kognitif yang lebih tingg ${ }^{[5]}$ (Kuru, S. et.al, 2007). Hakikat masalah dalam PBM adalah adanya kesenjangan antara situasi nyata dan kondisi yang diharapkan atau antara kenyataan yang terjadi dengan yang diharapkan, yang menimbulkan keresahan, keluhan, kerisauan atau kecemasan. Beberapa kriteria pemilihan bahan pelajaran dalam PBM yakni: (1) harus isu-isu yang mengandung konflik atau conflict issue; (2) bersifat familiar bagi siswa; (3) berhubungan dengan kepentingan orang banyak; (4) mendukung tujuan atau kompetensi yang harus dimiliki oleh siswa sesuai kurikulum; (5) sesuai dengan minat siswa ${ }^{[6]}$ (Sanjaya, 2007).

\section{B. Pemanfaatan Simulasi Komputer dalam Pembelajaran}

Perkembangan di bidang teknologi informasi memberikan pengaruh yang cukup besar bagi dunia pendidikan, khususnya dalam proses pembelajaran. Menurut Rosenberg ${ }^{[7]}$ (Surya, 2006) terdapat lima pergeseran dalam proses pembelajaran dengan berkembangnya penggunaan teknologi informasi yaitu, (1) dari pelatihan ke penampilan, (2) dari ruang kelas ke di mana dan kapan saja, (3) dari kertas ke "online" atau saluran, (4) dari fasilitas fisik ke fasilitas jaringan kerja, (5) dari waktu siklus ke waktu nyata.

\section{Keterampilan Berpikir Kritis}

Berpikir kritis terdiri dari tiga bagian, yaitu (1) berpikir kritis melibatkan mengajukan pertanyaan. Ini berkaitan dengan apa yang perlu ditanyakan, mengajukan pertanyaan yang baik, pertanyaan yang masuk ke inti permasalahan. Berpikir kritis melibatkan kesadaran bahwa ada pertanyaan yang perlu ditangani. (2) berpikir kritis berkaitan dengan usaha mencoba untuk menjawab pertanyaan melalui penalaran. (3) berpikir kritis berkaitan dengan kepercayaan pada hasil penalaran ${ }^{[8]}$ (Nosics.G, 2012).

\section{Metode Penelitian}

Penelitian ini termasuk penelitian kuasi eksperimen dengan disain pretest-posttest control group design. Subjek penelitian ini adalah Mahasiswa 
yang sedang mengikuti perkuliahan Fisika Dasar pada Program Studi Pendidikan Fisika pada sebuah LPTK di Mataram pada tahun akademik 2008/2009. Instrumen yang digunakan adalah tes penguasaan konsep berbentuk pilihan ganda yang terdiri dari 31 soal. Pengolahan data dilakukan dengan menghitung skor gain ternormalisasi dan uji perbedaan dua rerata. Persamaan yang digunakan untuk menghitung $\langle\mathrm{g}\rangle$ adalah:

$$
\mathrm{g}=\frac{\mathrm{S}_{\text {post }}-\mathrm{S}_{\text {pre }}}{\mathrm{S}_{\text {max }}-\mathrm{S}_{\mathrm{pre}}} \times 100 \%
$$

dengan kategori: tinggi : $\mathrm{g}>70$; sedang : $30 \leq \mathrm{g} \leq 70$ ; dan rendah : $\mathrm{g}<30^{[8]}$. (Cheng, et al, 2004)

Pengolahan data penelitian diawali dengan uji statistik berupa uji normalitas dan uji homogenitas. Selanjutnya dilakukan uji perbedaan dua rerata untuk menguji tingkat signifikasi perbedaan rerata skor tes penguasaan konsep kedua kelas (kelas eksperimen dan kelas kontrol).

\section{HaSil dan PEMBahasan}

\section{A. Keterampilan Berpikir Kritis Mahasiswa Secara Umum}

Indikator keterampilan berpikir kritis yang menjadi pokok bahasan dalam penelitian ini meliputi kemampuan menemukan persamaan dan perbedaan, kemampuan memberikan alasan, kemampuan membuat kesimpulan, dan kemampuan menggunakan prinsip yang dapat diterima. Masing-masing indikator dianalisis ketercapaiannya berdasarkan perolehan skor tes awal, tes akhir, dan gain yang dinormalisasi. Peningkatan keterampilan berpikir kritis mahasiswa dieksplorasi berdasarkan jawaban tes awal dan tes akhir setelah mengikuti pembelajaran. Hasil penilaian keterampilan berpikir kritis berupa skor yang kemudian dihitung persentasenya. Perbandingan persentase pencapaian peningkatan skor rata-rata tes awal, tes akhir dan $\mathrm{N}$-Gain keterampilan berpikir kritis antara kelas eksperimen dan kelas kontrol dengan jumlah mahasiswa 27 orang ditunjukkan pada gambar grafik di bawah.
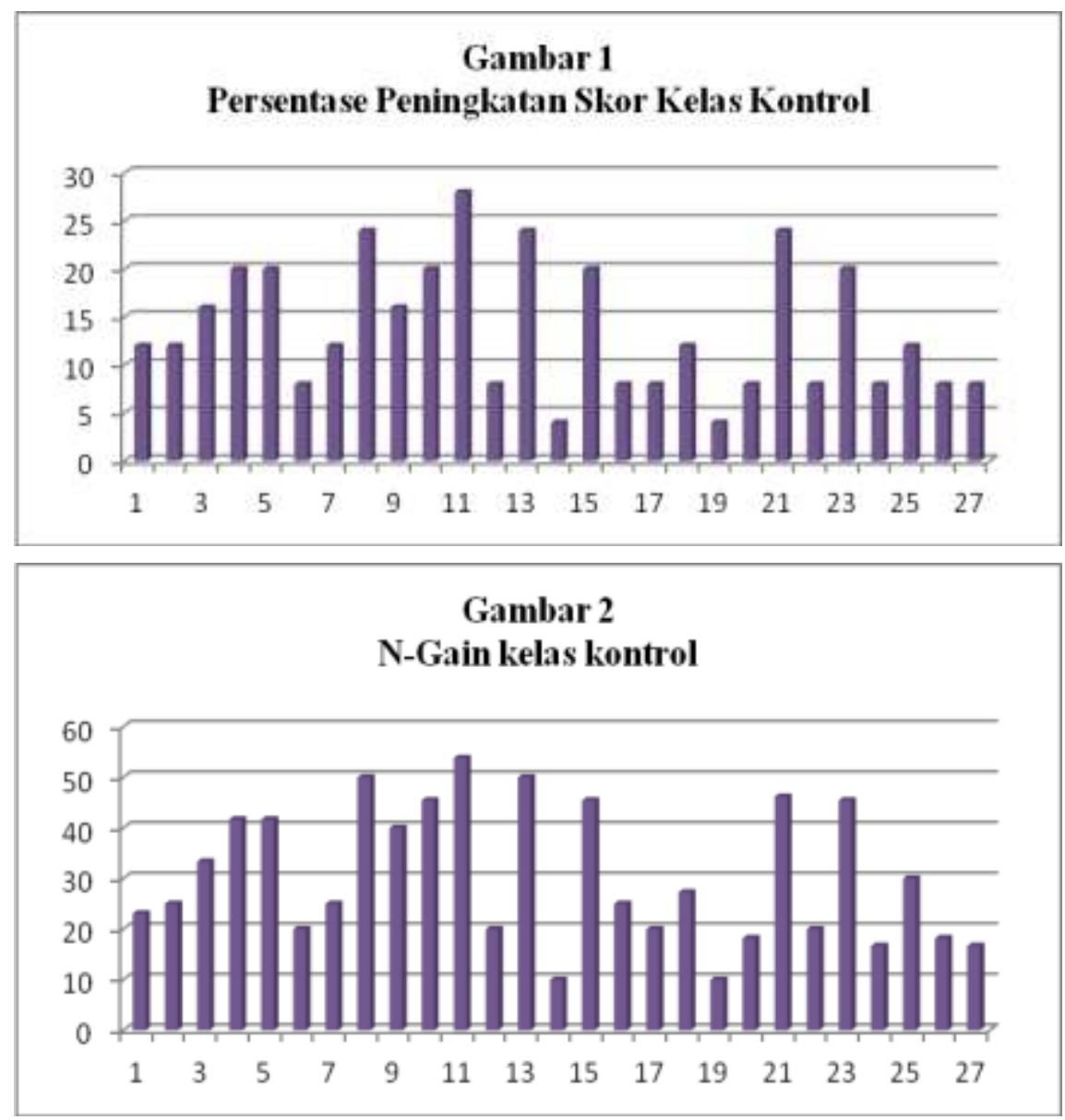

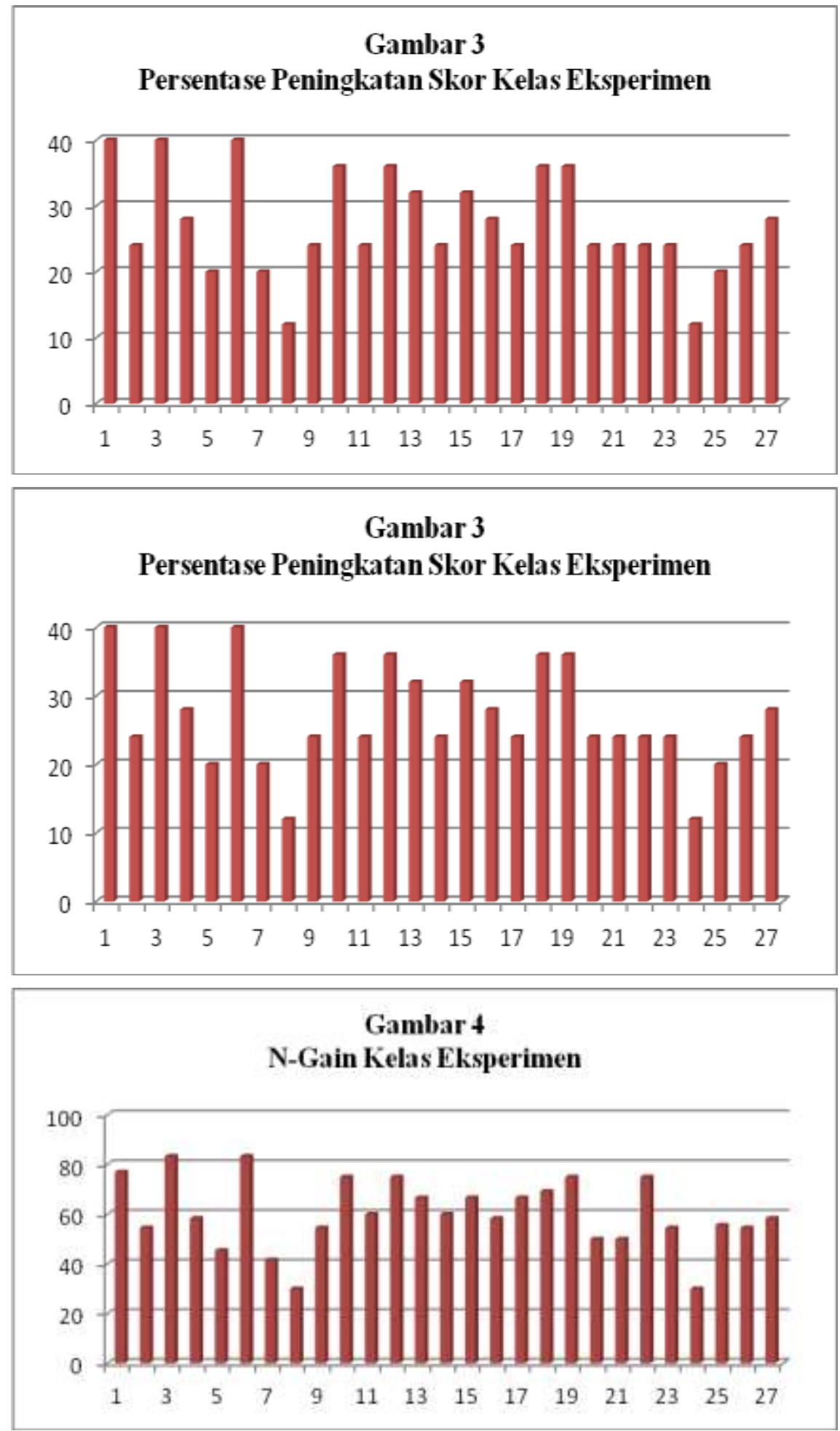

Data penelitian menunjukkan bahwa terjadi peningkatan keterampilan berpikir kritis pada kedua kelas dengan persentase yang berbeda. Untuk kelas eksperimen peningkatan tertinggi terjadi pada indikator berkategori Kemampuan menemukan persamaan dan perbedaan sebesar $40 \%$ Artinya bahwa model pembelajaran berbasis masalah berbantuan simulasi komputer dapat membantu mahasiswa dalam membuat pertimbanganpertimbangan untuk membedakan dan menemukan persamaan pada kasus pengembangan dari permasalahan dengan benar. 


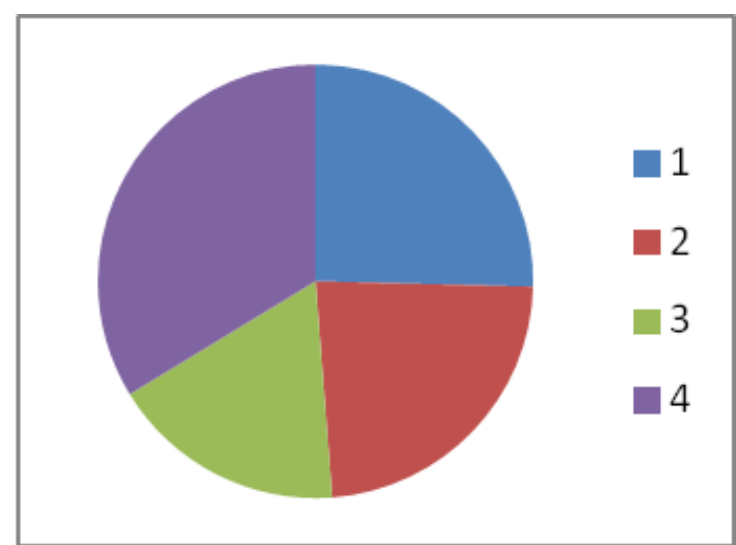

Gambar 5. Diagram kemampuan berpikir kritis tiap indikator pada pretest kelas kontrol

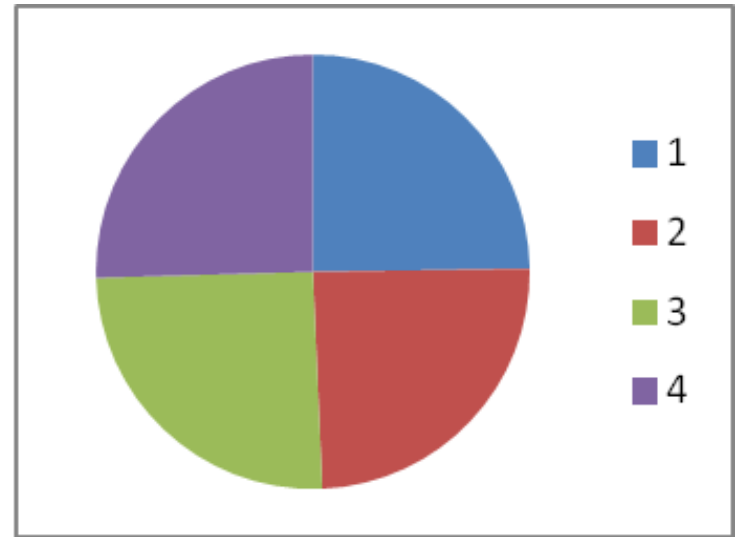

Gambar 6. Diagram kemampuan berpikir kritis tiap indikator pada postes kelas kontrol

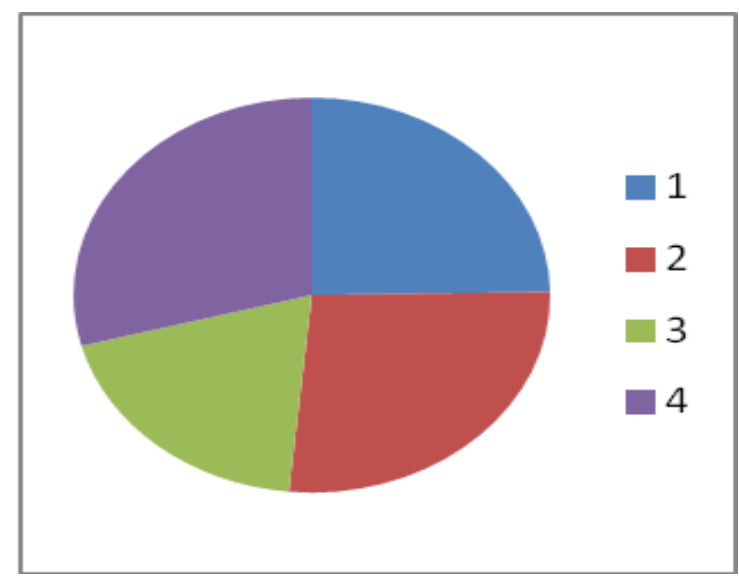

Gambar 7. Diagram kemampuan berpikir kritis tiap indikator pada pretest kelas eksperimen

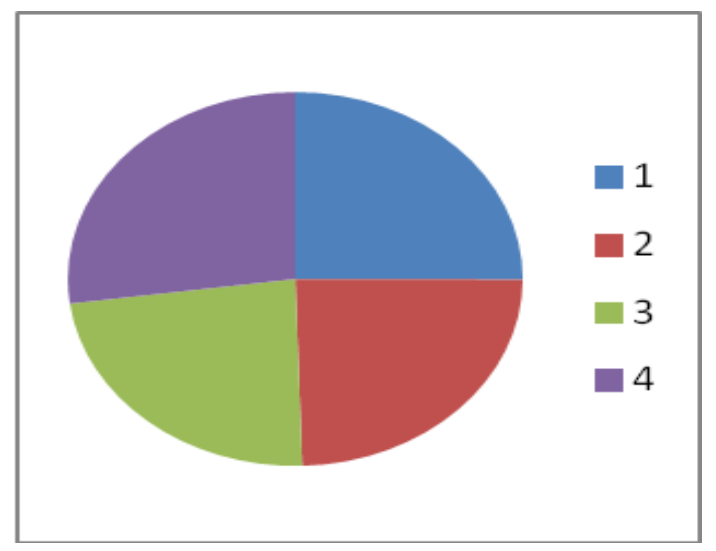

Gambar 8. Diagram kemampuan berpikir kritis tiap indikator pada pretest kelas ksperimen

\section{Keterangan Indikator}

1. Kemampuan menemukan persamaan dan perbedaan

2. Kemampuan menemukan alasan

3. Kemampuan membuat kesimpulan

4. Kemampuan menggunakan prinsip yang dapat diterima

Berdasarkan data tes awal dan tes akhir pada gambar (7) dan (8) terlihat bahwa skor rata-rata kelas eksperimen yang mengalami peningkatan tertinggi sebesar $40 \%$ dan terendah sebesar $12 \%$. Sedangkan skor rata-rata kelas kontrol mengalami peningkatan tertinggi sebesar $28 \%$ dan terendah sebesar $4 \%$. Rata-rata N-Gain pada kelas eksperimen yang berkategori tinggi sebesar 19\% atau sejumlah 5 orang dari 27 mahasiswa dan sisanya berkategori sedang yaitu $81 \%$. Sedangkan pada kelas kontrol, jumlah mahasiswa yang berkategori rendah sebesar $44 \%$, dan sisanya berkategori sedang sebesar $56 \%$. Rata-rata NGain kelas eksperimen maupun rata-rata N-Gain kelas kontrol sebagian besar termasuk dalam kategori sedang. Namun, berdasarkan data tersebut terlihat bahwa rata-rata $\mathrm{N}$-Gain keterampilan berpikir kritis mahasiswa kelas eksperimen lebih tinggi dibandingkan rata-rata $\mathrm{N}-$ Gain kelas kontrol.

Secara umum peningkatan keterampilan berpikir kritis pada setiap indikator mengalami peningkatan, baik pada kelas eksperimen maupun kelas kontrol. Peningkatan indikator keterampilan berpikir kritis kelas eksperimen umumnya lebih tinggi dibandingkan kelas kontrol. Skor rata-rata keterampilan berpikir kritis dapat ditinjau berdasarkan setiap indikator yang dikembangkan. 


\section{PENUTUP}

Peningkatan berpikir kritis pada konsep listrik statis bagi mahasiswa yang memperoleh pembelajaran berbasis masalah berbantuan simulasi komputer lebih tinggi secara signifikan dibandingkan dengan mahasiswa yang memperoleh pembelajaran konvensional. Dosen dan mahasiswa memberikan tanggapan positif terhadap model pembelajaran berbasis masalah berbantuan simulasi komputer pada materi listrik statis. Model pembelajaran berbasis masalah memberikan pengaruh positif dalam upaya meningkatkan keterampilan berpikir kritis mahasiswa.

\section{UCAPAN TERIMA KASIH}

Ucapan terima kasih diucapkan kepada DP2M DIKTI sebagai pihak yang telah membiayai penelitian ini.

\section{REFERENSI}

[1] Herayanti, Lovy. (2009). "Model Pembelajaran Berbasis Masalah dengan Pendekatan Inkuiri untuk Meningkatkan Penguasaan Konsep Calon Guru Pada Materi Listrik Statis". Jurnal Penelitian Pendidikan IPA. Volume 3 Nomor 2.

[2] Herayanti, Lovy. (2012). "Model Pembelajaran Berbasis Masalah dengan Pendekatan Inkuiri untuk Meningkatkan Keterampilan Generik Sains Mahasiswa”. Jurnal Kependidikan. Vol 11 No. 1.

[3] Tan,Ong-Seng. (2009). Problem-based Learning and Creativity. Singapore: Cengage Learning Asia Pte. Ltd.

[4] Gunawan. (2011). "Model multimedia interaktif elastisitas dan implikasinya terhadap peningkatan penguasaan konsep dan keterampilan berpikir kritis mahasiswa". Jurnal Kependidikan, Vol 10 No. 1.

[5] Kuru, S. et. al. (2007). Problem Based Learning. Teaching and Research in Engineering in Europe.

[6] Sanjaya, W. (2007). Strategi Pembelajaran Berorientasi Standar Proses Pendidikan. Jakarta: Kencana Prenada Media Group.
[7] Surya, M. (2006). Potensi Teknologi Informasi dan Komunikasi Dalam Peningkatan Mutu Pembelajaran di Kelas. Makalah dalam Seminar Pemanfaatan TIK untuk Pendidikan Jarak Jauh dalam Rangka Peningkatan Mutu Pembelajaran, diselenggarakan oleh Pustekkom Depdiknas, tanggal 12 Desember 2006 di Jakarta.

[8] Nosics, G.M. (2012). Learning to Think Things Through. Boston: Pearson Education. Inc

[9] Cheng, K., dkk. (2004). Using Online Homeworks Systems Enhances Student. Learning of Physics Concept in an Introductory Physics Course. American Journal of Physics. 72 (11) 1447-1453.

\section{Biografi Penulis}

Lovy Herayanti, M.Pd, Lahir di Mataram pada tanggal 3 Juni 1981. Gelar Sarjana Pendidikan Fisika diperoleh pada Program sarjana di Universitas Mataram tahun 2003 dan melanjutkan kembali pada program Pascasarjana UPI dibidang Pendidikan fisika tahun 2007. Saat ini masih mengabdi sebagai Dosen tetap di IKIP Mataram. Pengalaman di bidang riset terfokus pada kajian permasalahan dunia pendidikan. Riset-riset yang telah dilakukan berupa riset dibidang internal, riset untuk Dosen Pemula (PDP), dan riset untuk hibah bersaing.

Habibi, M.Pd, Lahir di Lombok Tengah pada tanggal 27 Pebruari 1983. Gelar Sarjana Fisika diperoleh pada Program sarjana di Universitas Negeri Yogyakarta tahun 2008 dan melanjutkan kembali pada program Pascasarjana Pendidikan IPA UNRAM tahun 2012. Saat ini masih mengabdi sebagai Dosen tetap pada institusi pendidikan IKIP Mataram. Pengalaman di bidang riset terfokus pada kajian permasalahan dunia pendidikan fisika. Riset-riset yang telah dilakukan berupa riset dibidang internal, riset untuk Dosen Pemula (PDP), dan riset untuk hibah bersaing. 